\title{
The Minimum Required Landscape Discharge
}

\author{
Magdalena Klich $^{1, *}$ Konrad Thürmer ${ }^{2}$ \\ ${ }^{1}$ Institut für Wasserwirtschaft, Siedlungswasserbau und Ökologie, Coudray Straße 4, 99423 Weimar, Germany \\ ${ }^{2}$ Brandenburg University of Technology Cottbus-Senftenberg, Siemens-Halske-Ring 8, 03046 Cottbus, Germany
}

\begin{abstract}
Due to challenges of ecological restoration of post-mining areas to pre-operational conditions in aspect of water quality and quantity, development and assessment of ecological based minimal landscape discharge is necessary. In order to determine it, the basic nature and human factors and their relations within a catchment area had to be described and the essential parameters defined. The hydro ecological relations in the landscape are described by means of the numerous measurement methods and interpretation algorithms. The further aim was these procedures and the interpretation thresholds concerning the Minimum Required Landscape Discharge to recognize and optimally adapt for application.
\end{abstract}

\section{Introduction}

The Lusatian lignite mining area is a demanding water management region. In this area there are 25 open-pit lakes with a total water surface of 14,800 ha. A large number of formerly natural rivers have been constructed. The aquifer is also affected by the dewatering.

Due to the complex relationships with respect to the expenditure to reestablish the post-mining water balance, it is necessary to find methods that allow making proper decision for measures, technologies and investments.

The objectives of the project were to define the requirements on the Minimum Required Landscape Discharge (Landschaftsnotwendiger Mindestabfluss, LNA) and to find the proper or adjustable to the requirements modeling tool to determine this discharge.

\section{Methods}

\section{The Minimum Required Landscape Discharge - Requirements}

The Minimum Required Landscape Discharge shall serve as a decisive factor to restore, preserve or develop specific landscape conditions. The parameters dependent on the water availability determine the condition of flora and fauna but also the climate, area topology and anthropogenic impact.

In order to define the Minimum Required Landscape Discharge in post-mining areas, the basic nature and human factors, like landscape constraints, historical reference conditions, climate change, spatial dependencies, land use legacies etc. and their relations within a defined catchment area had to be described, categorise (Fig. 1) and the essential parameters defined.

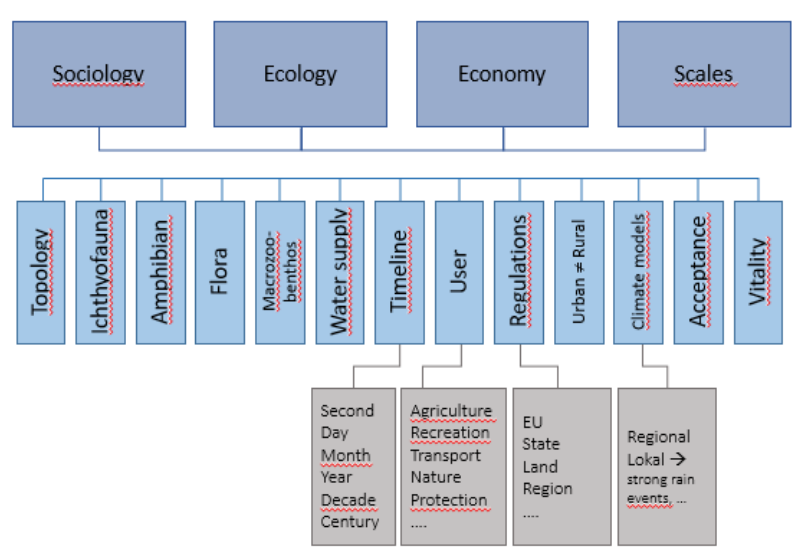

Fig. 1 Classification

The hydro-ecological relations in the landscape are described through numerous measurement methods and interpretation algorithms. The further aim was these procedures and the interpretation thresholds concerning the objectives to recognize and optimally adapt for application.

\section{Parameter}

One of the parameter is "History" (Past). The basis for the assessment of the LNA in post-mining areas are the pre-conditions of the land. Protection goals should be derived from the anthropogenic changes in the landscape. The milestones within the genesis process should determine the demands on the landscape and thus on the water balance. (Fig. 2)

\footnotetext{
Corresponding author: magdalena.klich@iwsoe.de
} 


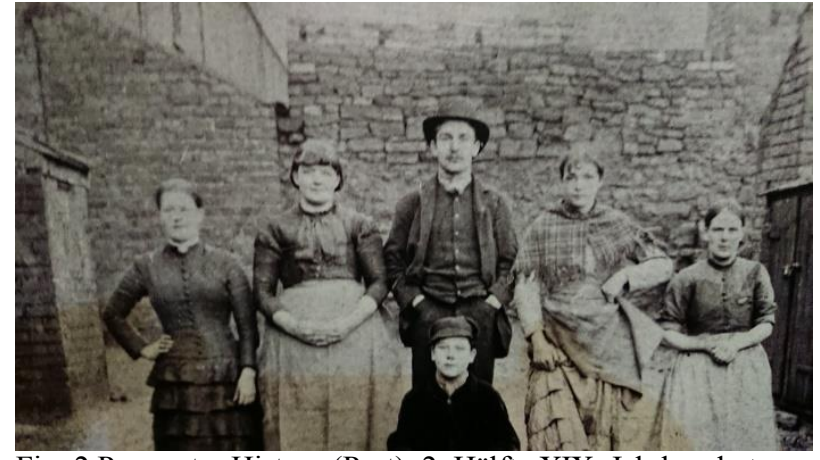

Fig. 2 Parameter History (Past), 2. Hälfte XIX. Jahrhundert

For carrying out diverse tasks in the responsibility area of federal and state authorities in the field of water management, the availability of adequately secured factual information about extreme events (high and low water) as well as hydraulic engineering systems is very important.

It is worthwhile to include in the analysis apart of recent documents (since around 1960), also the older ones (gauge and lysimeter data, construction documents, building surveys, site plans and construction drawings).

State and local archives are important storage locations for old documents.

The other parameter is "Law". The regulations, like state water law, federal state water law, nature conservation law, federal state nature conservation law, forestry law, surface water decree, riparian buffer strip data sheet etc. appoint an action field.

The parameter "User" includes different user and interest groups, like nature conservation, agriculture, forestry, natural reserve, potable water, green areas, manufacturing trade, industry.

For example, the parameter "Forestry" Water consumption depends on the species inventory (Tab. 1), the age of the population, the climatic conditions and the topology of the catchment area.

\begin{tabular}{|c|c|c|}
\hline $\begin{array}{l}\text { Tree } \\
\text { species }\end{array}$ & Leaf mass $\left(\mathrm{kg} \mathrm{ha}^{-1}\right)$ & $\begin{array}{l}\text { Water requirements } \\
\text { of forests }\left(1 \mathrm{~m}^{-2} \text { year }^{-1}\right)\end{array}$ \\
\hline Birch & 4,940 & $430-480$ \\
\hline Beech & 7,900 & $320-370$ \\
\hline Larch & 13,950 & $460-580$ \\
\hline Pine & 12,550 & $240-300$ \\
\hline Spruce & 31,000 & $390-450$ \\
\hline Douglas fir & 40,000 & $480-580$ \\
\hline
\end{tabular}

Table 1 Water consumption [1]

The next parameter is "Agriculture". The daily water consumption in the main growth period with largely unrestricted evapotranspiration conditions plays the basic role in water balance.

The further parameter is "Evaporation". The climatic drive of the evaporation variables results from the vapor pressure deficit in the air, the air temperature and the convective water vapor transport.

According to DWA M 504 [2], the determination of evaporation cannot be adequately defined in terms of management, since the amount of evaporation fluctuates considerably in accordance with land use, vegetation and orography, as well as the soil conditions.

The further parameter is "Topology". The amount, quality and time course of the runoff or infiltration and thus the usable water availability in a catchment area depend on the climate, geology and topography.

Damping and deceleration processes during transport influence the runoff process.

Analysis of the topological diversities in the distribution approaches, allows determination how the shared runoff is again concentrated as an area runoff.

The next parameter is "Water quantity". The amount of available water (as a control factor) consists of the natural supply in the catchment area and of the managed supply (dams, groundwater maintenance).

Changes in Parameter "Water quality" (substance concentration, water temperature) are of crucial importance in various areas of water use, such as potable water, agriculture, industry as well as the receiving water and nature conservation.

The other parameter is "Soil type". A specific quantity of water determined by texture, soil density, organic content, stone fraction and thickness of the soil layer is stored in the soil. In most soils, the majority of water is available to plants.

Since evaporation is the essential parameter in the water budget and this in turn depends on kind of vegetation, the change in soil type has a substantial influence.

The other parameter that determines the distribution and flow of water in the soil is "Vegetation". A considerable part of the rainwater is retained in the canopy and evaporates directly from there. The root water absorption in the soil is differentiated by the distribution of the roots and the stomata limit transpiration in response to a decreased leaf water potential.

The parameters and dimensions generate different relations (Fig. 3). The scale levels determine the parameters on which the relations are based. 


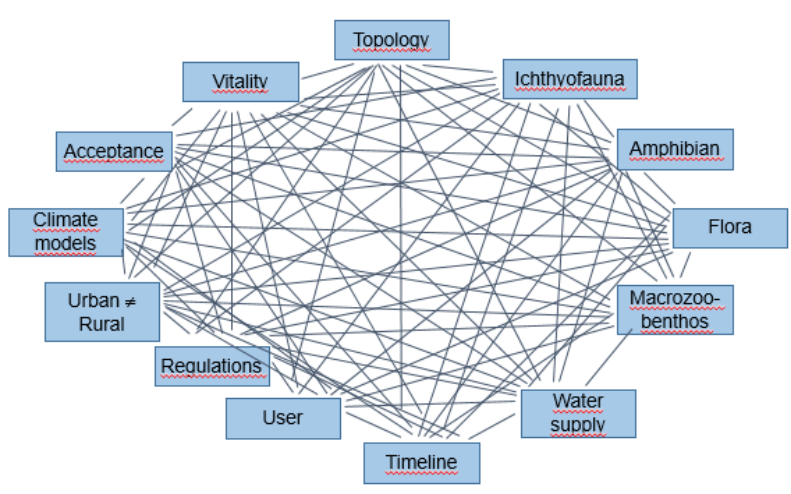

Fig. 3 Relations

For example, relation "Space". For reliable relations the scale levels have to be defined. Area (qualitative):

River / aquifer

River bank / floodplain

Catchment area $\quad 100 \mathrm{~km}^{2}$

$1,000 \mathrm{~km}^{2}$

$10,000 \mathrm{~km}^{2}$

But it is also possible to define the scale levels and the intersection for relation "Time". Time (qualitative):

Second (runoff), Minute (rain yield factor), Hour (residence time), Day (transpiration of cultivated plant), Year (sediment transport), Decade (young forest) and century (clime).

\section{Restrictions}

The restrictions are inherent system components to reduce the degrees of freedom. Starting from a clear relation up to only stochastically verifiable relations, the parameters have to be defined which serve as support points within the chosen system.

The simplest restriction within the system is the stationary flow in the receiving water.

$$
\begin{array}{lr}
\text { Brahms / de Chezy } & \mathrm{v}=\mathrm{C} \sqrt{R I} \\
\text { Reynolds } & \mathrm{Re}=\frac{v D}{v} \\
\text { Froude } & \mathrm{Fr}=\frac{v}{\sqrt{g L}}
\end{array}
$$

One of the restrictions is "Potable water". For the assessment of potable water resource, the sociological studies of the age structure, population density, share of small businesses, traditions and sensitivity have to be quantified.

The further restriction is "Agriculture". The natural supply limits production on agricultural land. The natural potential is derived from the above parameters. The provided quantities of water decide on the selection of crops and the amount of production.
Also the restriction "Climate change" can be consider as a function of restriction. However, the long-term strategies for adapting to changed parameters such as temperature, precipitation distribution and wind have an impact on short-term decisions and must therefore be quantified.

\section{Methods}

The basic method for determining the minimum discharge required for the landscape is the ranking of scenarios. Stringent bases of the scenarios are decisionbased procedures, whereby the parameters cannot be weighted equally.

\section{Conclusions}

Cultural landscape

In the cultural landscape, not all users are served at the same time by the available range.

The decisive factor is which users, i.e. which target values are defined and justified and thus find acceptance. Due to the changing natural and social framework, the short-term establishment of a balance is not possible.

\section{Acceptance}

The large number of degrees of freedom in the system on the one hand result in a restriction of users and target sizes and on the other hand the acceptance of precisely these specifications.

\section{Budget}

All measures initiated over time must be viewed in monetary terms. The total costs are only of limited significance. The measures are defined by the definition of users and target values.

\section{Acknowledgments}

Publication is funded by the Polish National Agency for Academic Exchange under the International Academic Partnerships Programme from the project „Organization of the $9^{\text {th }}$ International Scientific and Technical Conference entitled Environmental Engineering, Photogrammetry, Geoinformatics - Modern Technologies and Development Perspectives".

\section{Literature:}

1. H. Lyr, H.-J. Fiedler, W. Tranquillini, Physiologie und Ökologie der Gehölze. Gustav Fischer Verlag Jena, Stuttgart. 1992

2. ATV-DVWK Deutsche Vereinigung für Wasserwirtschaft, Abwasser und Abfall. (2002): Merkblatt M 504. Verdunstung in Abhängigkeit von Landnutzung, Bewuchs und Boden. ATV-DVWKRegelwerk. 